\title{
Stability of SARS-CoV-2 on the Surfaces of Three Meats in the Setting That Simulates the Cold Chain Transportation
}

\author{
Xiao-Li Feng ${ }^{1} \cdot$ Bei Li ${ }^{2} \cdot$ Hao-Feng Lin ${ }^{2,3} \cdot$ Hong-Yi Zheng ${ }^{4} \cdot$ Ren-Rong Tian ${ }^{4} \cdot$ Rong-Hua Luo ${ }^{4} \cdot$ \\ Mei-Qin Liu ${ }^{2,3} \cdot$ Ren-Di Jiang ${ }^{2,3} \cdot$ Yong-Tang Zheng $^{1,4} \cdot$ Zheng-Li Shi $^{2} \cdot$ Yu-Hai Bi ${ }^{3,5}$ (D) Xing-Lou Yang ${ }^{2}$ (I)
}

Received: 9 October 2020 / Accepted: 1 February 2021 / Published online: 8 April 2021

(c) Wuhan Institute of Virology, CAS 2021

\section{Dear Editor,}

The coronavirus disease 2019 (COVID-19) pandemic presents a severe threat to public health and the global economy and the direct origin of the causative agent severe acute respiratory syndrome coronavirus 2 (SARS-CoV-2) remains unresolved (WHO 2020). The outbreak in China was successfully contained by the implementation of a strict quarantine strategy, however sporadic outbreaks still occurred and were associated with trade markets in Beijing and Dalian cities. The COVID-19 outbreak in Beijing was traced to contaminated salmon meat sold at the Xinfadi market, Beijing, China (Chinese CDC 2020), causing by a viral strain belonging to the B1.1 lineage, which firstly identified and mainly circulated in Europe, indicating that the strain had transferred from another country (Yang et al. 2020). Later, the Chinese Center for Disease Control and Prevention detected the nucleic acid of SARS-CoV-2 from over ten samples of imported frozen shrimp and chicken meat products in several cities in China (Chen and Duan 2020). Additionally, outbreaks associated with slaughterhouses and meat-packing factories in Portugal, Ghana, UK,

Xiao-Li Feng, Bei Li and Hao-Feng Lin have contributed equally to this work.

\footnotetext{
Xing-Lou Yang

yangxl@wh.iov.cn

$\triangle$ Yu-Hai Bi

beeyh@im.ac.cn
}

1 Kunming National High-Level Biosafety Research Center for Non-Human Primates, Center for Biosafety Mega-Science, Kunming Institute of Zoology, Chinese Academic of Sciences, Kunming 650107, China

2 CAS Key Laboratory of Special Pathogens, Wuhan Institute of Virology, Center for Biosafety Mega-Science, Chinese Academy of Sciences, Wuhan 430071, China

3 University of Chinese Academy of Sciences, Beijing 101408, China and Australia were reported (Waltenburg et al. 2020). The spread of SARS-CoV-2 from workers to food products is conceivable. Hence, food safety and the analysis of the potential relation between food and the outbreaks of COVID-19 are of great significance. Here, we aimed to determine the stability of SARS-CoV-2 on meat surfaces in the setting that simulates the cold chain transportation, in order to provide scientific advice for transmission control.

Pork, beef, and frozen salmon meat were bought from supermarkets (Wuhan \& Kunming) and cut into cubes that weighed approximately 1-2 g per cube. The stock SARSCoV-2 (IVCAS 6.7512 in Wuhan and NMDCNO00HUI in Kunming) (Zhou et al. 2020) was diluted with Dulbecco's modified Eagle's medium (DMEM) (Gibco) to $10^{3}$ or $10^{4}$ $\mathrm{TCID}_{50} / \mathrm{mL}$. The meat was immersed in the DMEM containing SARS-CoV-2 at $10^{3}$ or $10^{4} \mathrm{TCID}_{50} / \mathrm{mL}$ for $10 \mathrm{~s}$. Later, these cubes were transferred into a 6-well plate and then stored at $4{ }^{\circ} \mathrm{C}$ or $-20{ }^{\circ} \mathrm{C}$ to simulate the temperature of cold chain transportation. Meat samples were taken out at different time points, and each cube was transferred to 24 wells plate and rinsed 20 times with $1 \mathrm{~mL}$ of DMEM. Each type of meat sample was tested in two to six technical replicates at each time point (Table 1). Then, $140 \mu \mathrm{L}$ of washing medium was used to extract viral RNA using the

4 Key Laboratory of Animal Models and Human Disease Mechanisms of the Chinese Academy of Sciences, Kunming Institute of Zoology, Chinese Academy of Sciences, Kunming 650223, China

5 CAS Key Laboratory of Pathogenic Microbiology and Immunology, Institute of Microbiology, Center for Influenza Research and Early-Warningarning (CASCIRE), CASTWAS Center of Excellence for Emerging Infectious Diseases (CEEID), Chinese Academy of Sciences, Beijing 100101, China 
Table 1 Isolation rates of SARS-CoV-2 from washing liquids of different meat samples.

\begin{tabular}{|c|c|c|c|c|c|c|}
\hline & \multicolumn{3}{|c|}{$10^{3} \mathrm{TCID}_{50} / \mathrm{mL}$} & \multicolumn{3}{|c|}{$10^{4} \mathrm{TCID}_{50} / \mathrm{mL}$} \\
\hline & Pork & Beef & Salmon & Pork & Beef & Salmon \\
\hline \multicolumn{7}{|l|}{$4{ }^{\circ} \mathrm{C}$} \\
\hline $0 \mathrm{~h}$ & $5 / 6$ & $5 / 6$ & $3 / 6$ & $6 / 6$ & $6 / 6$ & $6 / 6$ \\
\hline $12 \mathrm{~h}$ & $4 / 6$ & $3 / 6$ & $6 / 6$ & $6 / 6$ & $6 / 6$ & $6 / 6$ \\
\hline $24 \mathrm{~h}$ & $4 / 6$ & $4 / 6$ & $4 / 6$ & $6 / 6$ & $6 / 6$ & $6 / 6$ \\
\hline $36 \mathrm{~h}$ & $4 / 6$ & $3 / 6$ & $3 / 6$ & $6 / 6$ & $6 / 6$ & $4 / 6$ \\
\hline $48 \mathrm{~h}$ & $3 / 6$ & $5 / 6$ & $2 / 6$ & $6 / 6$ & $6 / 6$ & $5 / 6$ \\
\hline $72 \mathrm{~h}$ & $6 / 6$ & $6 / 6$ & $3 / 6$ & $6 / 6$ & $6 / 6$ & $5 / 6$ \\
\hline $144 \mathrm{~h}$ & / & / & I & $2 / 2$ & $2 / 2$ & $2 / 2$ \\
\hline $216 \mathrm{~h}$ & / & I & I & $2 / 2$ & $1 / 2$ & $1 / 2$ \\
\hline \multicolumn{7}{|l|}{$-20^{\circ} \mathrm{C}$} \\
\hline $0 \mathrm{D}$ & $5 / 6$ & $5 / 6$ & $4 / 6$ & $6 / 6$ & $5 / 6$ & $6 / 6$ \\
\hline $1 \mathrm{D}$ & $4 / 6$ & $6 / 6$ & $3 / 6$ & $6 / 6$ & $6 / 6$ & $6 / 6$ \\
\hline $2 \mathrm{D}$ & $5 / 6$ & $6 / 6$ & $5 / 6$ & $6 / 6$ & $6 / 6$ & $6 / 6$ \\
\hline $3 \mathrm{D}$ & $5 / 6$ & $5 / 6$ & $3 / 6$ & $5 / 6$ & $6 / 6$ & $6 / 6$ \\
\hline $4 \mathrm{D}$ & $6 / 6$ & $6 / 6$ & $2 / 6$ & $6 / 6$ & $6 / 6$ & $5 / 6$ \\
\hline $5 \mathrm{D}$ & $6 / 6$ & $6 / 6$ & $2 / 6$ & $6 / 6$ & $6 / 6$ & $6 / 6$ \\
\hline $6 \mathrm{D}$ & $0 / 3$ & $2 / 3$ & $1 / 3$ & $3 / 3$ & $3 / 3$ & $3 / 3$ \\
\hline $7 \mathrm{D}$ & $2 / 3$ & $3 / 3$ & $2 / 3$ & $2 / 3$ & $3 / 3$ & $3 / 3$ \\
\hline $9 \mathrm{D}$ & $1 / 2$ & $0 / 2$ & $1 / 2$ & $1 / 2$ & $2 / 2$ & $0 / 2$ \\
\hline $15 \mathrm{D}$ & $1 / 2$ & $1 / 2$ & $2 / 2$ & $2 / 2$ & $1 / 2$ & $1 / 2$ \\
\hline $20 \mathrm{D}$ & $0 / 2$ & $0 / 2$ & $1 / 2$ & $1 / 2$ & $1 / 2$ & $1 / 2$ \\
\hline
\end{tabular}

Virus isolation successful repeats/total repeats.

Viral RNA kit (Roche, Germany), and the viral RNA extracted in the washing medium was amplified using quantitative reverse-transcription polymerase chain reaction (qRT-PCR) targeting the spike genes of SARS-CoV-2 (Mabsky Biotech Co., Ltd., China). The limit of detection (LOD) of the kit was 610 viral RNA copies/mL. Additionally, $200 \mu \mathrm{L}$ of the washing medium was used to infect Vero E6 cells (ATCC no. CRL-1586) in a 24-well plate. Three days later, the supernatant in each well was collected to detect the viral RNA by qRT-PCR; meanwhile, the cells were washed thrice with $1 \times$ phosphate buffered saline $(\mathrm{pH}$ 7.4) and then fixed with $4 \%$ paraformaldehyde to detect the viral nucleocapsid protein using the indirect immunofluorescence assay (IFA) as described previously (Zhou et al. 2020). The viral isolation was considered successful from either qRT-PCR or IFA-positive test results of the infected cell or the culture supernatant. Meat samples were collected at $0,12,24,36,48,72,144$, and $216 \mathrm{~h}$ after stored at $4{ }^{\circ} \mathrm{C}$, and at $0,1,2,3,4,5,6,7,9,15$, and 20 days after stored at $-20{ }^{\circ} \mathrm{C}$ (Table 1 ).

From the samples containing low viral titers stored at $4{ }^{\circ} \mathrm{C}$, viral RNA could be detected in the washing fluids of all the samples until $72 \mathrm{~h}$ post-infection (hpi) (Fig. 1A).
The average number of viral RNA copies was higher in pork meat samples than in beef and salmon meat samples. The number of viral RNA copies in low titers-treated salmon samples was lower than the LOD number of the kit. In samples containing high viral titers stored at $4{ }^{\circ} \mathrm{C}$, viral RNA could be detected in the washing fluids of all the samples until $216 \mathrm{hpi}$, and the viral RNA copies in three types of meat samples show no significant difference (Fig. 1B). The average number of viral RNA copies showed no decline over time, both in the low and high viral titer groups. Regarding viral isolation, live viruses could be isolated on Vero E6 cells from samples stored at $4{ }^{\circ} \mathrm{C}$ at all the time points, but not from all of the technical replicates (Table 1). The viral isolation rates in three types of meat samples show no significant difference. At high viral concentration, the virus was successfully isolated from all washing liquid samples of pork and beef until 6 days postinfection (dpi). However, the isolation rate was lower from the samples of salmon meat. At 9 dpi, the highest live-virus isolation rate was measured from the samples of pork meat.

In meat samples containing low viral titers stored at $-20{ }^{\circ} \mathrm{C}$, viral RNA could be detected in the washing fluids of all the samples until $20 \mathrm{dpi}$ at the experiment ending point (Fig. 1C). The average number of viral RNA copies was lower in the salmon meat sample than in the beef and pork meat samples. The number of viral RNA copies in all three meat samples was lower than the LOD number of the kit after 7 dpi. In meat samples containing high viral titers stored at $-20^{\circ} \mathrm{C}$, viral RNA could be detected in the washing fluids of all samples until $20 \mathrm{dpi}$ (Fig. 1D). The viral RNA copies in three types of meat samples show no significant difference. The number of viral RNA copies was lower than the LOD number of the kit after 9 dpi. Regarding viral isolation, live viruses could be isolated on Vero E6 cells from all of the samples, but were not successful in all the technical replicates (Table 1). The virus was successfully isolated from the washing fluid samples of all the pork and beef meat samples until $6 \mathrm{dpi}$; however, the isolation rate decreased over time.

In this study, we tested three types of meat stored under two different storage temperatures after inoculation with two different viral concentrations. Viral RNA and live viruses could be detected or isolated from the surface of meat samples collected at different time points. Viral RNA copies were lower on salmon compared with pork and beef, which may be caused by the different texture and fat content of the meat. The viral isolation rate showed no difference under $4{ }^{\circ} \mathrm{C}$ and $-20{ }^{\circ} \mathrm{C}$ before $3 \mathrm{dpi}$; however, the viral isolation rate of the frozen meat samples $\left(-20^{\circ} \mathrm{C}\right)$ was higher than that of the fresh storage meat samples $\left(4{ }^{\circ} \mathrm{C}\right)$ after $3 \mathrm{dpi}$. Recently, a study published in bioRxiv tested the viral stability in chicken, pork, and salmon meat samples, and found that the viral titer does not 

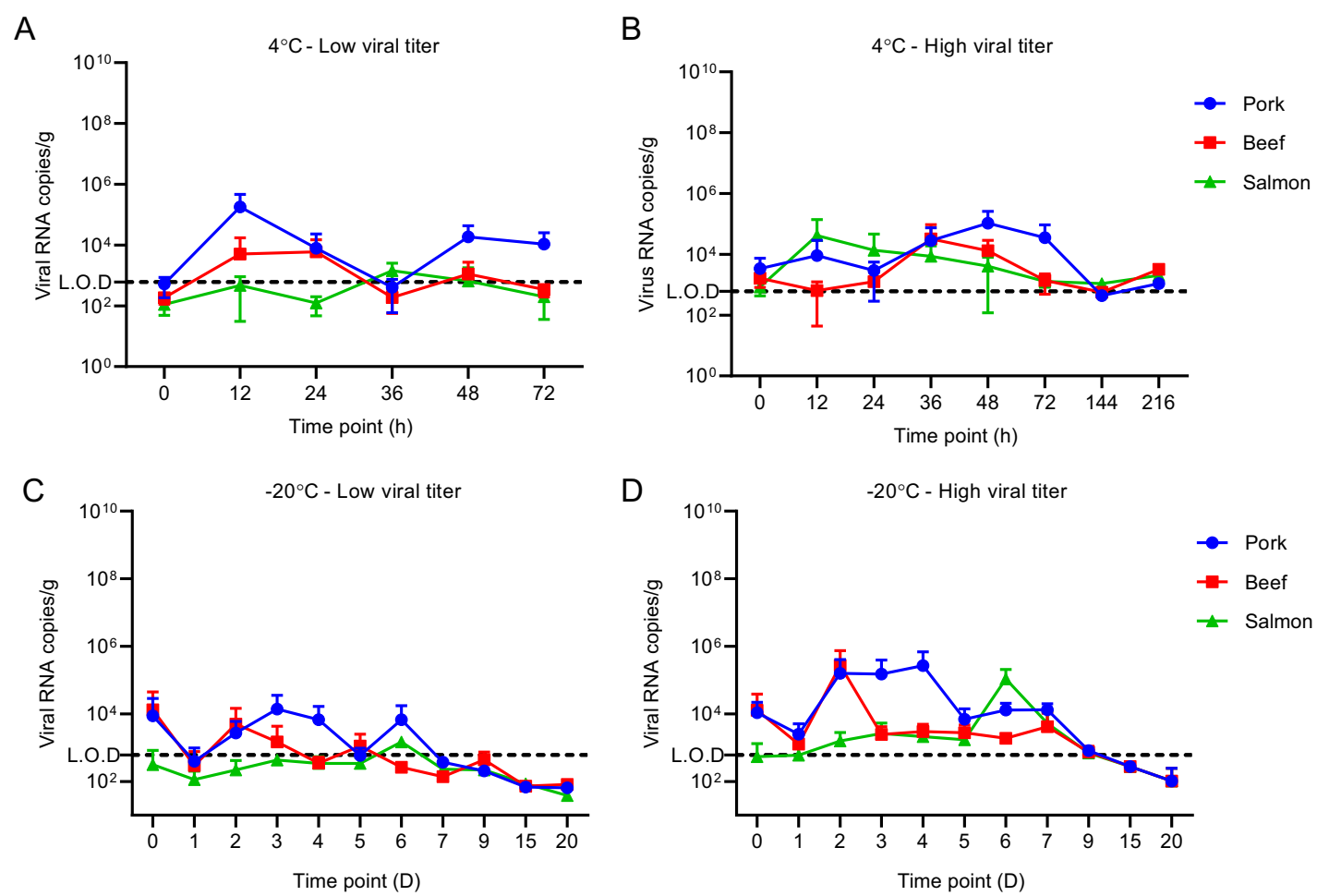

Fig. 1 Number of viral RNA copies in the washing liquid of different meat samples. The washing medium was used to extract viral RNA using the Viral RNA kit (Roche, Germany), and the viral RNA extracted in the washing medium was amplified using quantitative reverse-transcription polymerase chain reaction (qRT-PCR) targeting the spike genes of SARS-CoV-2 (Mabsky Biotech Co., Ltd., China).

The LOD of the kit was 610 copies of RNA/mL. LOD, limit of detection. A Viral RNA copies in the washing fluids of low viral titers stored at $4{ }^{\circ} \mathrm{C}$; B Viral RNA copies in the washing fluids of high viral titers stored at $4{ }^{\circ} \mathrm{C}$; $\mathbf{C}$ Viral RNA copies in the washing fluids of low viral titers stored at $-20{ }^{\circ} \mathrm{C}$; D Viral RNA copies in the washing fluids of high viral titers stored at $-20^{\circ} \mathrm{C}$.

reduce at $4{ }^{\circ} \mathrm{C},-20{ }^{\circ} \mathrm{C}$, and $-80{ }^{\circ} \mathrm{C}$, respectively, for 3 weeks (Fisher et al. 2020). However, the viral concentration used in the study was as high as $3 \times 10^{6}$ TCID $_{50} /$ $\mathrm{mL}$, which is significantly higher than the viral titers present in clinical respiratory samples $\left(1 \times 10^{3}\right.$ to $1 \times 10^{4}$ $\mathrm{TCID}_{50} / \mathrm{mL}$ ) that correspond to $10^{7}-10^{8}$ viral RNA copies/ $\mathrm{mL}$ (Pan et al. 2020; To et al. 2020; Zhang et al. 2020). In our study, we used two viral concentrations and tried to simulate the viral titers present in patient respiratory samples. For a better understanding of the survive time of live virus on the surface of different types of meats, we will carry out a study for a long-stored period in the future.

Generally, compared to those of the lower viral concentration group, samples containing a higher viral concentration had a higher number of viral RNA copies and higher viral isolation rates. However, the viral RNA detection rate is not consistent with the rate of viral isolation as the two methods have different sensitivity. Other groups tested the stability of SARS-CoV-2 at different temperatures and on different surfaces and found that SARS-CoV-2 is sensitive to high temperatures and dry conditions, but it is more stable at low temperatures (Chin et al. 2020; Fisher et al. 2020; van Doremalen et al. 2020). Given the stability of SARS-CoV-2 at low temperatures,

there is a risk of SARS-CoV-2 transmission from food products that are a part of the cold chain. Therefore, it is important to quarantine the staff working in food production, packaging, and transportation. We also suggest making necessary hygiene treatment and disinfection processes for food products, before consuming products transported by the cold chain.

Acknowledgements This work was supported by the Key Program of Chinese Academy of Sciences (KJZD-SW-L11 to Z.L.S.), the Strategic Priority Research Program of the Chinese Academy of Sciences (CAS) (XDB29010102 and XDA19090118 to Y.H.B.), COVID-19 emergency project of CAS (2020YJFK-Z-0149), the National Key R\&D Program of China (2020YFC0842000 to Y. T. Z.), the National Natural Science Foundation of China (NSFC32041010 to Y.H.B.), the NSFC Outstanding Young Scholars (31822055 to Y.H.B.), and Youth Innovation Promotion Association of CAS (2017122 to Y.H.B., 2019328 to X.L.Y.).

\section{Compliance with Ethical Standards}

Conflict of interest The authors declare that they have no conflict of interest.

Animal and Human Rights Statement This article does not contain any studies with human or animal subjects performed by any of the authors. 


\section{References}

Chinese CDC (2020) Progress of the COVID-19 in Beijing epidemic in June-July, http://www.chinacdc.cn/jkzt/crb/zl/szkb_11803/ jszl_11811/202007/t20200710_217703.html. Accessed 17 July 2020 (In Chinese)

Chin AWH, Chu JTS, Perera MRA, Hui KPY, Yen H-L, Chan MCW, Peiris M, Poon LLM (2020) Stability of SARS-CoV-2 in different environmental conditions. The Lancet Microbe 1:e10

Chen H, Duan XY (2020) How to import foreign food safely? http:// www.ccdi.gov.cn/toutiao/202008/t20200815_223796.html. Accessed 15 August 2020 (In Chinese)

Fisher D, Reilly A, Zheng AKE, Cook AR, Anderson DE (2020) Seeding of outbreaks of COVID-19 by contaminated fresh and frozen food. bioRxiv. https://doi.org/10.1101/2020.08.17.255166

Pan Y, Zhang DT, Yang P, Poon LLM, Wang QY (2020) Viral load of SARS-CoV-2 in clinical samples. Lancet Infect Dis 20:411-412

To KK, Tsang OT, Leung WS, Tam AR, Wu TC, Lung DC, Yip CC, Cai JP, Chan JM, Chik TS, Lau DP, Choi CY, Chen LL, Chan WM, Chan KH, Ip JD, Ng AC, Poon RW, Luo CT, Cheng VC, Chan JF, Hung IF, Chen Z, Chen H, Yuen KY (2020) Temporal profiles of viral load in posterior oropharyngeal saliva samples and serum antibody responses during infection by SARS-CoV-2: an observational cohort study. Lancet Infect Dis 20:565-574

van Doremalen N, Bushmaker T, Morris DH, Holbrook MG, Gamble A, Williamson BN, Tamin A, Harcourt JL, Thornburg NJ, Gerber SI, Lloyd-Smith JO, de Wit E, Munster VJ (2020) Aerosol and surface stability of SARS-CoV-2 as compared with SARS-CoV-1. N Engl J Med 382:1564-1567

Waltenburg MA, Victoroff T, Rose CE, Butterfield M, Jervis RH, Fedak KM, Gabel JA, Feldpausch A, Dunne EM, Austin C,
Ahmed FS, Tubach S, Rhea C, Krueger A, Crum DA, Vostok J, Moore MJ, Turabelidze G, Stover D, Donahue M, Edge K, Gutierrez B, Kline KE, Martz N, Rajotte JC, Julian E, Diedhiou A, Radcliffe R, Clayton JL, Ortbahn D, Cummins J, Barbeau B, Murphy J, Darby B, Graff NR, Dostal TKH, Pray IW, Tillman C, Dittrich MM, Burns-Grant G, Lee S, Spieckerman A, Iqbal K, Griffing SM, Lawson A, Mainzer HM, Bealle AE, Edding E, Arnold KE, Rodriguez T, Merkle S, Pettrone K, Schlanger K, LaBar K, Hendricks K, Lasry A, Krishnasamy V, Walke HT, Rose DA, Honein MA, C-R Team (2020) Update: COVID-19 among workers in meat and poultry processing facilities: United States, April-May 2020. MMWR Morb Mortal Wkly Rep 69:887-892

World Health Organization (WHO) (2020) Coronavirus disease (COVID-19) pandemic. https://www.who.int/emergencies/dis eases/novel-coronavirus-2019

Yang J, Niu P, Chen L, Wang L, Zhao L, Huang B, Ma J, Hu S, Wu L, Wu G, Huang C, Bi Y, Tan W (2020) Genetic tracing of HCoV-19 for the re-emerging outbreak of COVID-19 in Beijing, China. Protein Cell. https://doi.org/10.1007/s13238-020-00772-0

Zhang N, Gong Y, Meng F, Shi Y, Wang J, Mao P, Chuai X, Bi Y, Yang P, Wang F (2020) Comparative study on virus shedding patterns in nasopharyngeal and fecal specimens of COVID-19 patients. Sci China Life Sci. https://doi.org/10.1007/s11427-0201783-9:1-3

Zhou P, Yang XL, Wang XG, Hu B, Zhang L, Zhang W, Si HR, Zhu Y, Li B, Huang CL, Chen HD, Chen J, Luo Y, Guo H, Jiang RD, Liu MQ, Chen Y, Shen XR, Wang X, Zheng XS, Zhao K, Chen QJ, Deng F, Liu LL, Yan B, Zhan FX, Wang YY, Xiao GF, Shi ZL (2020) A pneumonia outbreak associated with a new coronavirus of probable bat origin. Nature 579:270-273 